\title{
A Financial Assessment of Windstorm Risks for Scots Pine Stands in Hemiboreal Forests
}

\author{
Janis Donis ${ }^{1}$, Renate Saleniece ${ }^{1}$, Oskars Krisans ${ }^{1}$, Edgars Dubrovskis ${ }^{2}$, Mara Kitenberga ${ }^{1}$ (D) \\ and Aris Jansons 1 ,* \\ 1 Latvian State Forest Research Institute, Silava, Rīgas Street 111, LV-2169 Salaspils, Latvia; \\ janis.donis@silava.lv (J.D.); sal.ren@yahoo.com (R.S.); oskars.krisans@silava.lv (O.K.); \\ mara.kitenberga@gmail.com (M.K.) \\ 2 Forestry Faculty, Latvia University of Life Sciences and Technologies, Liela iela 2, LV-3001 Jelgava, Latvia; \\ edgars.dubrovskis@llu.lv \\ * Correspondence: aris.jansons@silava.lv; Tel.: +371-29109529
}

Received: 31 March 2020; Accepted: 14 May 2020; Published: 18 May 2020

check for updates

\begin{abstract}
Windstorms are a significant disturbance in northern European Scots pine forests. Mechanistic models for assessment of their impact have been developed. The aim of our study was to assess the impact of windstorms on the financial value of Scots pine (Pinus sylvestris L.) stands. Wind damage probability in stands with certain dimensions (linked to age and site index) and the reduced value retrieved from salvage logging instead of planned harvest in undamaged stands were used for calculation. Equivalent annual annuity with interest rates of $3 \%, 4 \%$, and $5 \%$, three different commercial thinning regimes, and different planting densities were used to assess the mean influence. Wind damage risk had a notable and significant negative effect on the financial value of Scots pine forest stands. Equivalent annual annuity decreased sharply with stand age, especially in the most productive sites (SI 36). The negative financial impact could be reduced by selection of a lower initial planting density (1000-2000 trees ha ${ }^{-1}$ instead of 3000) and by reducing the rotation period, for example, by using target diameter as the criteria for the time of final harvest.
\end{abstract}

Keywords: wind damage; natural disturbance; critical wind speed; monetary value

\section{Introduction}

In Europe, an increase in the frequency of large-scale windstorms has been observed in recent decades [1]. Forestry is an economically important sector in numerous countries in northern Europe, and has the potential to remain as profitable in the future [2]. For example, in Latvia, forest sector products account for $20 \%$ of the total value of exports [3]. Windstorms cause notable losses for forest owners. Firstly, there is a financial loss due to lower wood value and quality $[4,5]$. Secondly, there are higher harvesting costs for salvage logging than an undamaged stand [6]. Thirdly, regenerating the stands requires unplanned expenses [7]. Following large-scale windstorms, the market overflows with salvage-logged timber, which causes a drastic price drop [7], therefore further decreasing the possibility of recovering a decent timber value after the windstorms.

Moreover, windstorms affect not only the economy of the wood-based sector but also recreation and other ecosystem services, such as habitat protection and carbon sequestration [8-10]. Hence, the development of policies to increase the resilience of forests and mitigate disturbance risk is important [11,12]. Wind damage risk can be addressed through national and regional forest policies, especially for forests at intermediate risk [13]. Appropriate policy instruments can greatly influence forest management practices, therefore enhancing adaptation efforts, which can be implemented as preventive measures, as well as financial support following disturbances [13]. However, the awareness 
of stakeholders and policymakers should be raised to develop such policies and integrate them into existing strategic planning documents, such as the National Forest Management Policy [14].

Various policies have been tested, including preventive measures and financial support following disturbances [13-15]. For example, in Sweden, after the 2005 windstorm "Gudrun", subsidies were implemented as part of risk management strategies to increase the proportion of more wind-resistant tree species [16]. However, in the decade that followed, this policy had no substantial effect. The main reasons for such an outcome are the lack of wind-resistant seedlings in nurseries, concerns about high-browsing pressure [17], and strong local silviculture traditions [18].

In northern Europe, Scots pine (Pinus sylvestris L.) is regarded as a more wind-resistant tree species than Norway spruce (Picea abies (L.) Karst.) due to a deeper root system and higher wood strength [19-21]. Still, in Europe, Scots pine can suffer extensive windstorm damage [22-24]. Such damage can be amplified by historic stand management activities, tree and stand characteristics, as well as windstorm strength and season $[19,22,24,25]$. Scots pine is the most widespread coniferous tree species in Latvia [26]. Therefore, the assessment of wind damage probability in Scots pine stands is both an ecologically and economically essential part of the risk mitigation strategy.

A timely risk assessment of windstorm damage would promote a deeper understanding of the efficiency of such measures, as well as any associated costs and benefits. Studies have shown that wind damage risk should be calculated over the whole rotation period [13]. Specific models, such as HWind $[19,20]$ or ForestGALES $[27,28]$, have been developed to conduct risk analysis, which can be part of a comprehensive mitigation policy. The aim of our study was to assess the impact of windstorms on the financial value of Scots pine stands within the rotation period. Considering the negative impact of tree dimensions on wind stability $[19,29]$, we hypothesised that the negative financial effect of wind damage risk would gradually increase with stand age. To test this hypothesis, we modelled wind damage probability and its impact on stands that had different initial planting densities. Subsequently, we calculated all the costs linked to forest management and compared the financial value with and without consideration of wind damage.

\section{Materials and Methods}

Latvia is located in the hemiboreal forest zone, located between $55^{\circ}$ and $58^{\circ} \mathrm{N}$ and $21^{\circ}$ and $28^{\circ} \mathrm{E}$ [30]. According to the National Forest Inventory, forests occupy $52 \%$ of its territory, and the most common tree species are birch (Betula pendula Roth and B. pubescens Ehrh.), Scots pine (Pinus sylvestris L.), and Norway spruce (Picea abies (L.) H. Karst.), comprising 27\%, 26\%, and 19\% of the total forest area, respectively [26].

In this study, the impact of wind damage risk on financial value was assessed in pure Scots pine stands on fertile soils with site indices (SI) of 36 and 32; such soils are rather common in Latvia, representing $17 \%$ and $30 \%$ of the total area of Scots pine stands in the country, respectively [26]. High returns from such stands are expected. Therefore, Scots pines are commonly planted in such conditions.

The financial impact of wind damage depends on (1) the probability of its occurrence and (2) its impact (the amount of damaged timber). The probability of wind damage depends on the wind, climate, and tree dimensions. We obtained tree dimensions at a specific age by using the local growth model [31]. Data on height growth is given in Table 1. The wind climate data were obtained from the Latvian Environment, Geology, and Meteorology Centre. In the models, the mean wind climate was characterised by the Weibull distribution (Equation (1)) [32]:

$$
f(v)=\frac{k}{A}\left(\frac{v}{A}\right)^{k-1} \exp \left(-\left(\frac{v}{A}\right)^{k}\right)
$$

where $v$ is the mean wind speed $\left(\mathrm{m} \mathrm{s}^{-1}\right)$, A is the scale parameter of the distribution, and $k$ is the form parameter of the distribution, set to 1.85 [32]. A is proportional to the mean wind speed. 
Table 1. Height growth and mean proportion of stands unaffected by wind.

\begin{tabular}{ccccccccccc}
\hline \multirow{2}{*}{ Parameter } & \multirow{2}{*}{ Indicator } & \multicolumn{10}{c}{ Age, Years } \\
\cline { 3 - 11 } & & $\mathbf{2 0}$ & $\mathbf{3 0}$ & $\mathbf{4 0}$ & $\mathbf{5 0}$ & $\mathbf{6 0}$ & $\mathbf{7 0}$ & $\mathbf{8 0}$ & $\mathbf{9 0}$ & $\mathbf{1 0 0}$ \\
\hline SI_32 & Hdom, m & 11 & 17 & 20 & 24 & 26 & 28 & 30 & 31 & 32 \\
SI_36 & Hdom, m & 14 & 19 & 23 & 27 & 30 & 32 & 34 & 35 & 36 \\
Wind-1 & Undamaged, \% & 100 & 99 & 98 & 97 & 96 & 93 & 85 & 75 & 71 \\
Wind-2 & Undamaged, \% & 100 & 99 & 98 & 95 & 91 & 84 & 74 & 67 & 58 \\
\hline
\end{tabular}

Hdom $=$ dominant height: height of 100 largest trees $\mathrm{ha}^{-1}$; Undamaged, $\%=$ proportion of stands without wind damage.

We used two scenarios to characterise regions with different wind climate conditions. The first scenario (Wind-1) was characterised by mild wind conditions, using a Weibull parameter A value of 5.0. The second scenario (Wind-2) characterised the windiest conditions close to the Baltic coast, with a Weibull parameter A value of 5.5. Empirical data-the maximum bending moment, relative crown height, and slenderness of the stem-were obtained from tree pulling experiments in Latvia that included 27 pines on mineral soil, which had a mean diameter at breast height (dbh) of $32.8 \pm 7.8 \mathrm{~cm}$ and a mean height of $27.4 \pm 2.7 \mathrm{~m}$ (unpublished). The critical wind speed needed for a tree with a specific diameter at the breast height ( $\mathrm{dbh}$ ) to be snapped or uprooted was determined using the conceptual framework defined by Quine [32]. The modelled mean proportion of stands unaffected by wind is summarised in Table 1.

When assessing the effects of wind damage, it was assumed that if the mean tree in a stand is damaged, the entire stand will be damaged and salvage logging will have to be conducted. The probability that the gust speed will exceed the critical wind speed was expressed as the proportion of stands destroyed over five years. The costs used in the financial calculations (Table 2) were taken from the 2018 database of the Central Statistical Bureau of Latvia [33].

Table 2. Forest management operations and their costs.

\begin{tabular}{|c|c|c|c|}
\hline Management Operation & & Costs & \\
\hline Soil preparation and planting & & 215.2 EUR ha $\mathrm{Ea}^{-1}$ & \\
\hline Plants & & 164.1 EUR (1000 plants $)^{-1}$ & \\
\hline Tending & & 103.4 EUR ha ${ }^{-1}$ & \\
\hline Pre-commercial thinning & & 124.1 EUR ha ${ }^{-1}$ & \\
\hline Logging & Final harvest, EUR $\mathrm{m}^{-3}$ & Thinning, EUR $\mathrm{m}^{-3}$ & Salvage-logging, EUR $\mathrm{m}^{-3}$ \\
\hline $\begin{array}{c}\text { Timber assortment preparation } \\
\text { (harvesting) }\end{array}$ & 5.70 & 9.39 & 9.85 \\
\hline Timber extraction (delivery) & 4.94 & 6.14 & $4.94-6.14$ \\
\hline $\begin{array}{c}\text { Timber transportation } \\
\text { (forwarding) }\end{array}$ & 5.90 & 6.07 & $5.90-6.07$. \\
\hline
\end{tabular}

An additional cost was the real estate tax of $4.8 \mathrm{EUR} \mathrm{ha}^{-1} \mathrm{year}^{-1}$.

During the simulation, the initial stand densities ranged from 1000 to 3000 pines ha $^{-1}$ (in steps of 500 trees $\mathrm{ha}^{-1}$ ). Two tendings and two pre-commercial thinnings were planned. The commercial thinnings were planned for a stand aged between 25 and 90 years. Three different, commonly applied commercial thinning regimes were modelled: (1) thinning occurs when the relative stand density reaches 0.95 and is reduced to $0.7 ;$ (2) thinning occurs when the relative stand density reaches 0.95 and is reduced to 0.45 ; and (3) thinning occurs when the relative stand density reaches 0.95 and is reduced to 0.45 in the first commercial thinning and 0.7 in the second thinning (see the resulting commercial thinning plans in Appendix A, Table A1).

The volume of the timber assortments was quantified based on the dimensions of the trees in the stand [34]. In salvage logging, the first (bottom) log was always assumed to be pulpwood. Income from the harvest (planned and salvage logging) was based on the volume and prices [28] of the timber assortments, as defined in Table 3. 
Table 3. Timber assortments and their prices.

\begin{tabular}{cccc}
\hline Timber Assortment & Minimum Top Diameter, $\mathbf{c m}$ & Minimum Length, $\mathbf{~}$ & Price, EUR $\mathbf{~ m}^{\mathbf{3}}$ \\
\hline Sawlogs I & $>26$ & 3.6 & 66.37 \\
Sawlogs II & $18.1-26$ & 3.6 & 62.78 \\
Sawlogs III & $14.1-18$ & 3.6 & 59.78 \\
Pulpwood & $10.1-14$ & 3 & 33.82 \\
Firewood & $6-10$ & 3 & 26.00 \\
\hline
\end{tabular}

The financial value of the stands was expressed by the equivalent annual annuity (EAA), which allowed us to compare mutually exclusive projects with unequal life spans and interest rates of 3\%, 4\%, and 5\% (Equation (2)) [35]:

$$
E A A=\frac{r \cdot \sum_{t=1}^{n} \frac{R_{t}}{(1+r)^{n \cdot 5}}}{1-(1+r)^{-n \cdot 5}}
$$

where $r$ is the interest rate of a 5 -year period $t(\%)$, Rt is the net cash inflow-outflow during $t$ (EUR), and $n$ is the number of 5-year periods.

\section{Results}

At interest rates of 3-5\%, the EAA reached its peak at an average of $40-45$ years when it was $45 \pm 5.5 \mathrm{EUR} \mathrm{ha}^{-1}$ (Figure 1). As the stands aged, their financial value gradually decreased. The value of stands older than 60 years was significantly different from the maximum. If the stand needed to be harvested after a disturbance (salvage-logged), the EAA demonstrated a similar age-related trend, but the values were negative independent from the stand age. The largest differences between the EAA of undamaged and salvage-logged stands were found at the age of 35-50 years, reaching on average $60 \pm 4.2 \mathrm{EUR} \mathrm{ha}^{-1}$, and it remained above $40 \mathrm{EUR} \mathrm{ha}^{-1}$ until the age of 85 years.

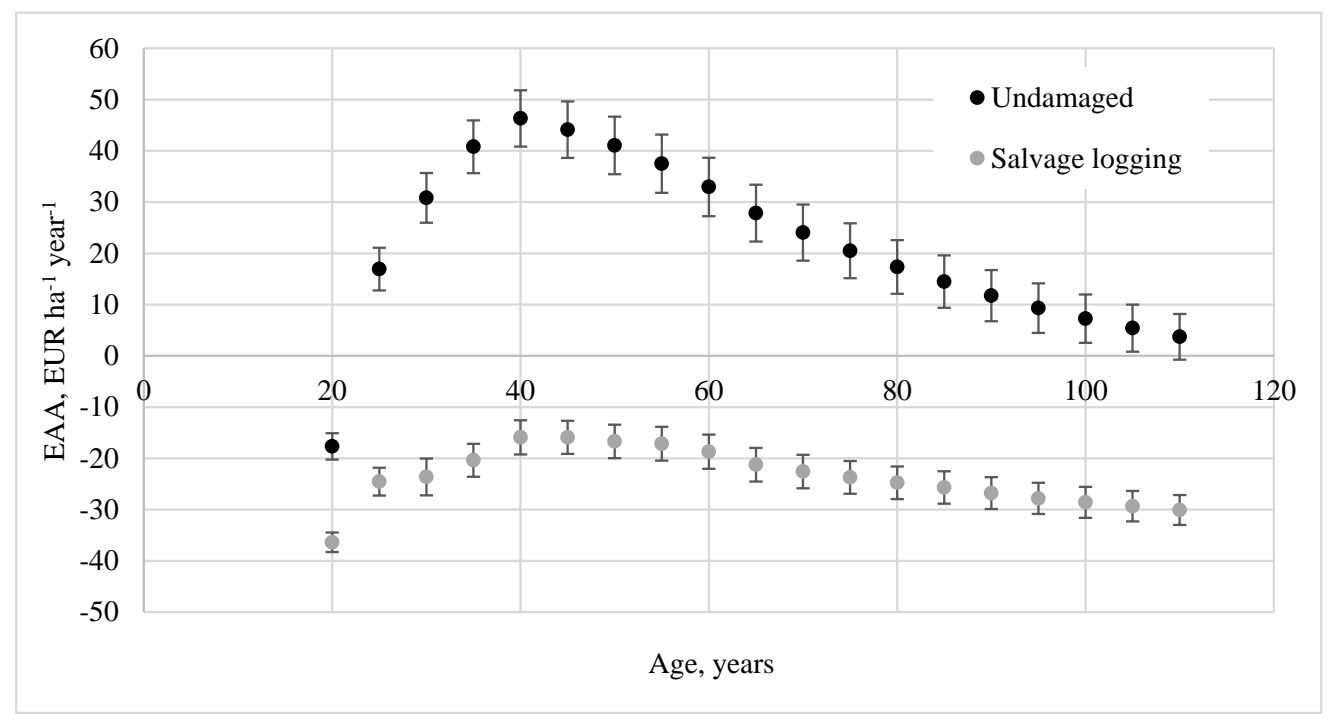

Figure 1. The average equivalent annual annuity (EAA) of planted Scots pine stands on fertile soils (SI 32 and SI 36) at different ages, applying a 3-5\% interest rate for undamaged and salvage-logged sites. Whiskers denote the $95 \%$ confidence intervals of the EAA.

The critical wind speed decreased with increasing stand age (Figure 2). At any given time, it was lower for stands on more fertile soils (higher site index) and in denser stands (3000 trees ha ${ }^{-1}$ vs. 1500 trees ha ${ }^{-1}$ ). At the age of 100 years, the modelled critical wind speed in SI 36 stands was $14.8-15.4 \mathrm{~m} \mathrm{~s}^{-1}$ but was $17 \mathrm{~m} \mathrm{~s}^{-1}$ in SI 32 stands. At this age, SI 36 stands had critical wind speeds 
below $20 \mathrm{~m} \mathrm{~s}^{-1}$ for $40-45$ years, but in SI 32 stands had these speeds for 20-25 years (depending on the density).

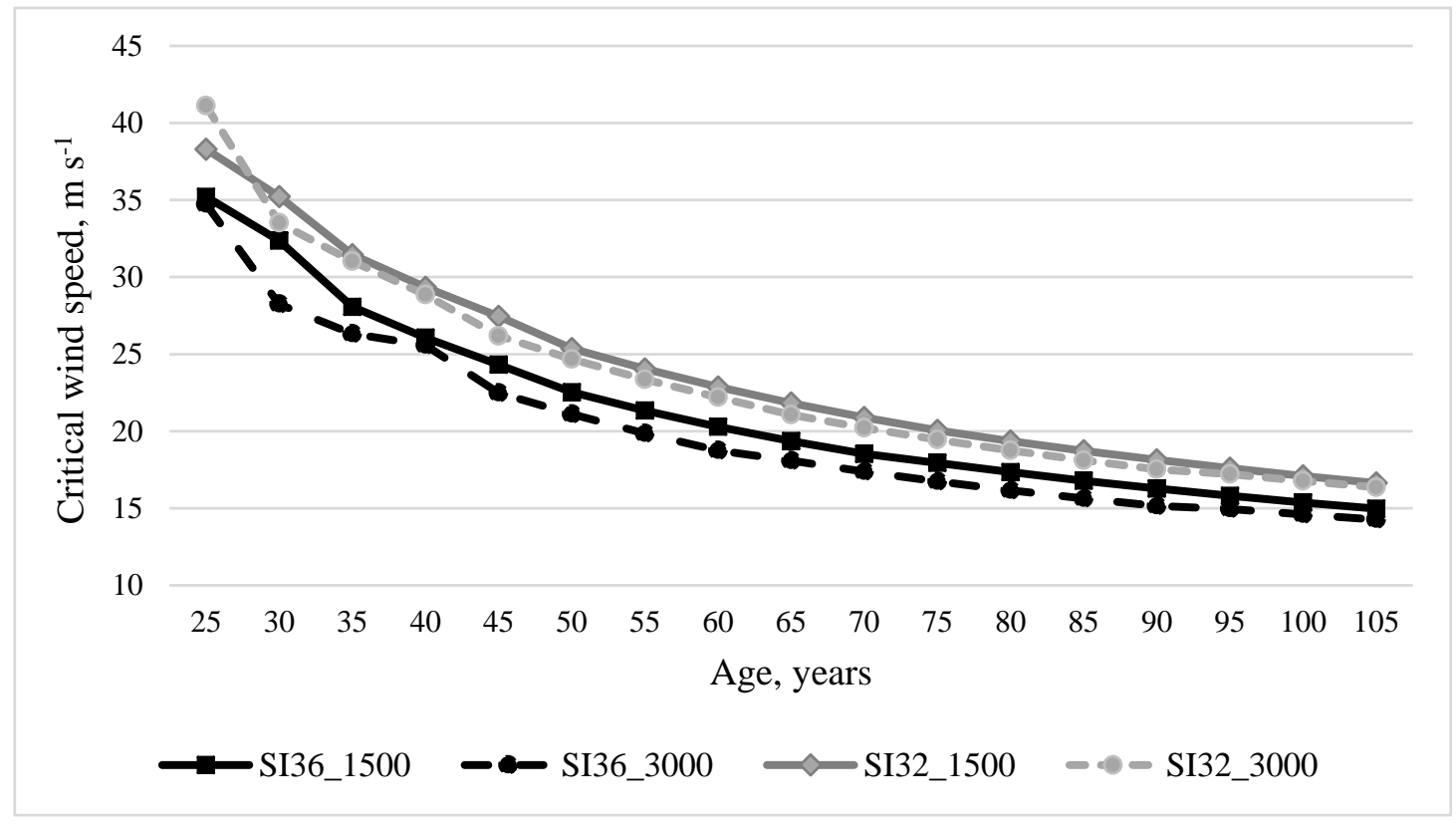

Figure 2. Changes in critical wind speed depending on the site index (SI) 36 and 32, as well as on initial stand density (numbers 1500 and 3000 —initial planting density, trees ha ${ }^{-1}$ ).

The wind damage risk did not influence the time of the peak EAA, nor its absolute value until the age of 50 years (Figure 3). However, the wind risk notably reduced the financial value as the stand became older. Due to lower critical wind speed in stands on fertile soils, the EAA value, initially higher, decreased more precipitously under these conditions (Figure 3). The EAA in SI 36 and SI 32 stands became equal at the age of 80 years and was statistically significantly lower in SI 36 at the age of 95 years. It was more than three times lower at the age of 110 years: the EAA in SI 36 was $-90 \pm 21.5 \mathrm{EUR}^{-1}$ and $-26 \pm 8.2 \mathrm{EUR} \mathrm{ha}^{-1}$ in SI 32 .

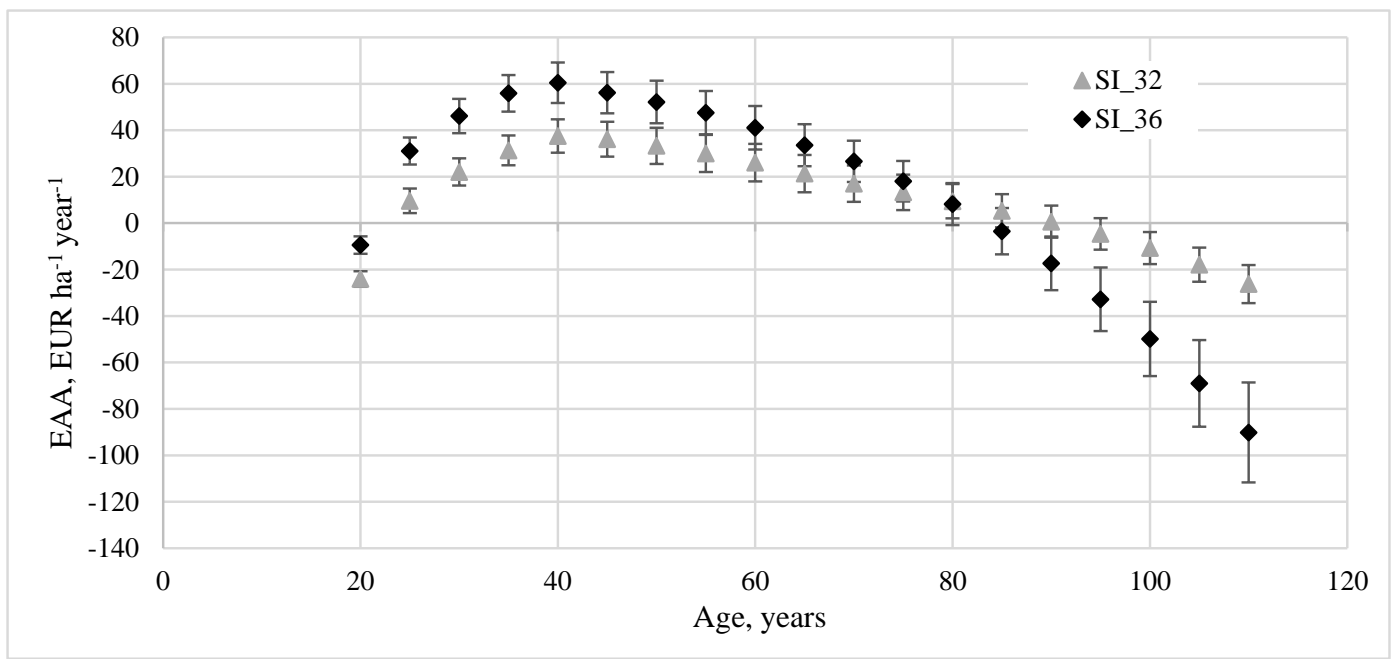

Figure 3. Equivalent annual annuity (EAA) of the planted Scots pine stands on fertile soil site index (SI) 36 and 32 at different age. Whiskers denote the $95 \%$ confidence intervals of the EAA.

A detailed analysis was performed for the 70-year stands, the age when the target diameter for the final harvest could be reached in hemiboreal forests, and for 100-year stands, corresponding to the 
final harvest age limit in several countries, including Latvia. If harvesting was performed at 70 years and the planting density had been 1000 or 2000 trees ha ${ }^{-1}$, the wind damage risk would have had a somewhat limited influence on the EAA, reducing it by $14 \%$ on average. However, with a higher initial density (3000 trees ha ${ }^{-1}$ ), the impact increased, reaching $40 \%$ on average (Figure 4 ). Yet, the observed differences were not statistically significant.

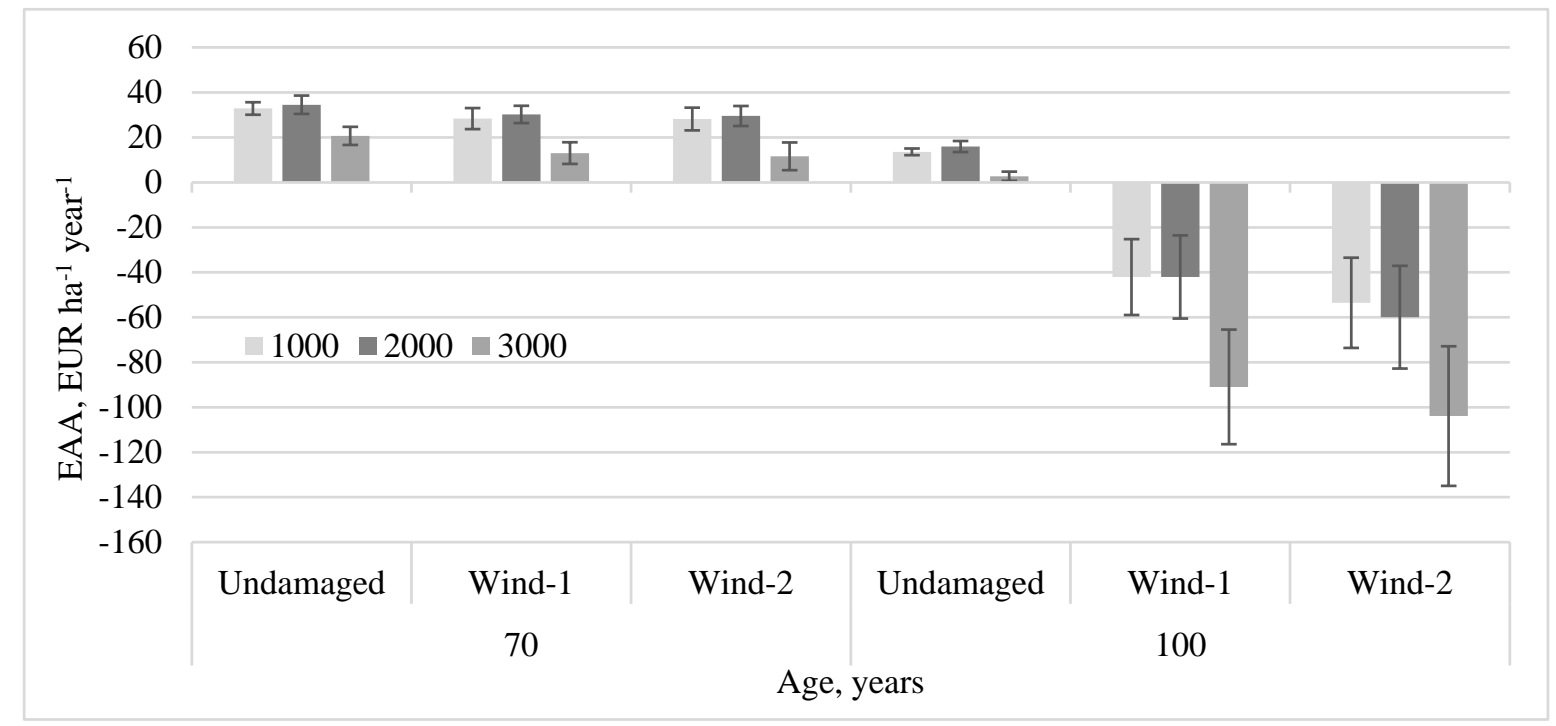

Figure 4. Equivalent annual annuity (EAA, $r=4 \%$ ) for the undamaged Scots pine stands (SI 36) and stands in mild wind conditions (Wind-1) and the windiest conditions (Wind-2), depending on the initial planting density (1000-3000 trees ha ${ }^{-1}$ ). Whiskers denote the $95 \%$ confidence intervals of the EAA.

The final harvest at 100 years of age reduced the EAA of the stands without wind risk by $66 \%$ on average (statistically significant, $p<0.05)$. A lower initial stand density (1000-2000 trees ha ${ }^{-1}$ ) with a wind damage risk at the age of 70 years had a significantly higher EAA than stands without wind damage at 100 years. Independent of the planting density, the EAA (4\% interest rate) values with wind damage risk were negative, notably and significantly different from the values without the risk. For the stand with a higher initial density (3000 trees ha ${ }^{-1}$ ), the lowest EAA values were observed (differences statistically significant for areas with a milder wind climate, Wind-1).

\section{Discussion}

Our study results showed that wind damage could cause major financial losses in Scots pine stands. The calculations showed that the critical wind speeds decreased with the stand age, and this decrease is sharper in the more productive (SI36) than less productive (SI32) sites. The tree's crown serves as a "sail" to catch larger wind loads and, with a taller tree stem (the lever arm), the critical wind speed value decreased, thus increasing the probability of wind damage $[28,36]$. Several studies have shown that wind damage risk increases with increasing stand age and height $[19,37]$.

The results of our calculations showed that, in all cases, a lower initial planting density increased the value of the EAA of the stand. Even if wind damage occurred, the financial losses were lower than in the stands with 3000 trees ha ${ }^{-1}$. A lower initial planting density tended to result in trees with larger diameters and thus a lower height to diameter ratio, which means higher wind stability than slender trees $[19,20]$. In similar soil conditions, the diameter also tended to have a positive correlation with rooting volume, which also improved wind stability [15]. Following the windstorm "Gudrun" in Sweden, the greatest damage was observed in recently thinned dense mature stands [21]. Thinning temporarily increases the risk of wind damage because individual trees become more exposed to higher wind loads to which they are not adapted [21]. In contrast, stands with a lower initial density tend to have better individual tree stability as they are adapted to exposure to a larger wind load than 
individual trees in denser stands [38]. A lower planting density also means a lower initial expenditure for plants.

The calculations of this study showed that a shorter rotation cycle-70 compared to 100 years, in combination with a lower initial planting density-ensured the highest EAA value. This combination was not strongly affected by the presence of wind damage, which might be explained by the relatively short period in which such stands were exposed to a high wind damage probability [15,39]. Our results suggest that, to obtain a higher EAA value, the minimal initial planting density per hectare should be decreased. For the highest site index and using age as the rotation criterion, a positive EAA can only be reached by establishing stands with an initial planting density as low as 1000 trees ha ${ }^{-1}$. Growth and yield studies carried out in Latvia, focusing on the influence of initial spacing and thinning on the radial increment of trees, showed that depending on silviculture measures, the target diameter could be reached considerably earlier than 100 years $[40,41]$. Hence, forest owners could mitigate wind damage risks considerably by decreasing the length of the rotation cycle.

The study is based on a growth model forecast; thus, any inaccuracies of this model would affect its results. We did not account for the short-term (3-5 years) negative impact of commercial thinning on stand stability, nor for the possible positive impact on stand stability in stands with a lower initial planting density (when trees in the stand are more likely to be better adapted to a wind regime). Additionally, we did not account for the influence of neighbouring stands, whether clear-cuts or similarly aged stands. These aspects, which were not included in the analysis, could have significant temporal positive and negative influences on the wind stability of the stand. We presumed that due to these dual (positive/negative) effects, on a larger scale, these factors might counterbalance each other, which would then minimise the overall effect. In the financial assessment, we did not include small-scale wind damage (individual tree damage) because individual damaged trees are rarely removed from the stand.

\section{Conclusions}

The probability and financial impact of wind damage need to be considered in long-term planning by forest owners and managers. Our results showed a decreasing EAA and critical wind speed with stand age (especially after 60 years). Thus, a long rotation cycle results in the loss of revenue and an increasing probability of wind damage, especially for the most productive (SI 36) sites, where the highest returns from the investment could be expected. After larger storms, falling prices of timber and rising logging costs can further increase the financial impact. The impact of wind damage, particularly in the windiest sites, can be reduced by selecting a lower initial planting density (1000-2000 trees ha ${ }^{-1}$ instead of 3000) and by reducing the length of the rotation cycle. Further research could address the full impact of wind damage on timber quality in salvage logging and the potential to reduce the probability of damage at the property (forest landscape) scale via changes in the spatial allocation of management activities.

Author Contributions: Conceptualisation, A.J. and J.D.; methodology, J.D.; writing-original draft preparation, R.S., M.K., A.J.; writing-review and editing, E.D., J.D., O.K.; project administration, A.J. All authors have read and agreed to the published version of the manuscript.

Funding: European Regional Development Fund, No 1.1.1.1/16/A/260.

Acknowledgments: This research was funded by the European Regional Development Fund Project Development of Decision support tool for the prognosis of storm damages in forest stands on peat soils (No. 1.1.1.1/16/A/260).

Conflicts of Interest: The authors declare no conflict of interest. 


\section{Appendix A}

Table A1. Resulting commercial thinning plans.

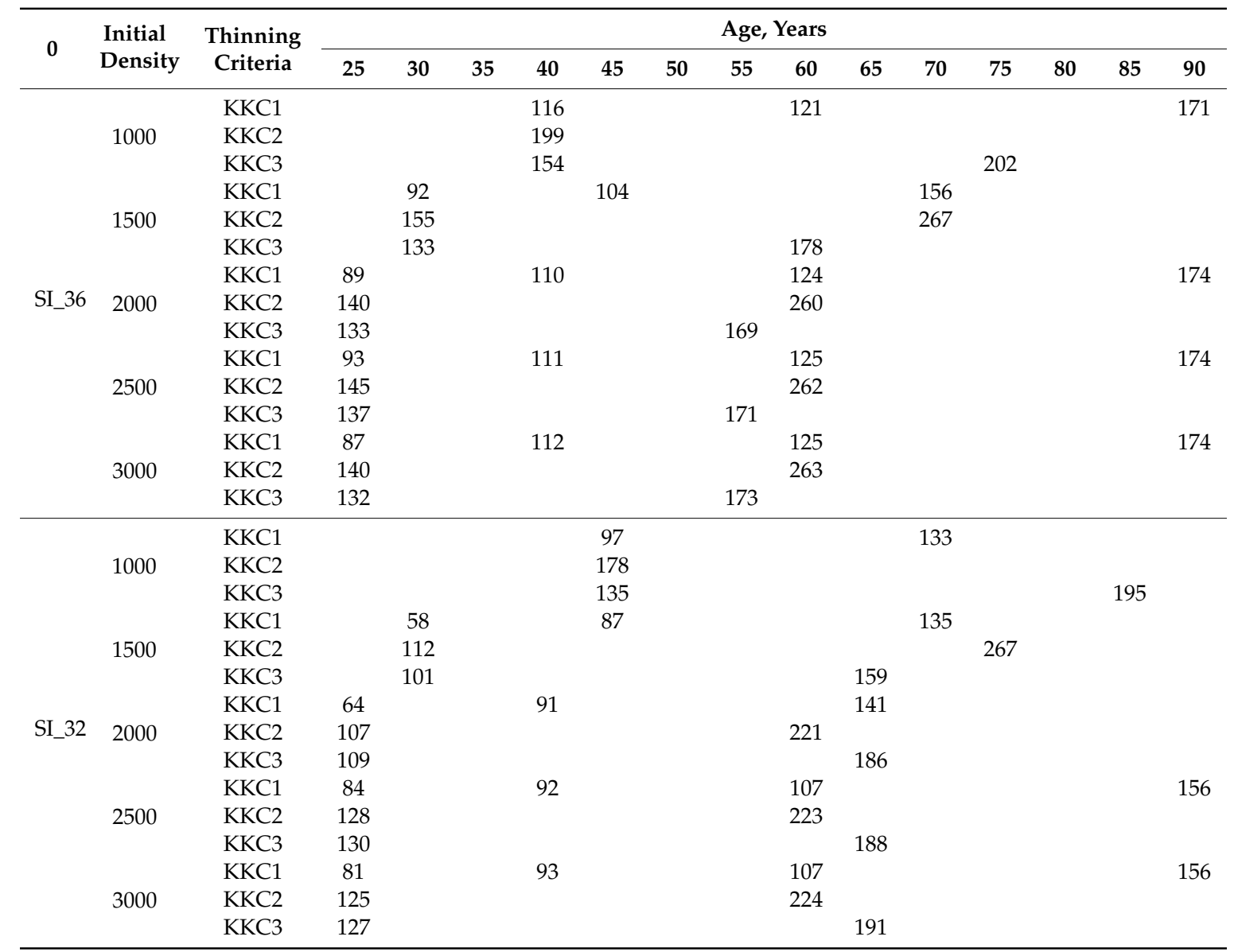

Commercial thinning schedule (removed volume, $\mathrm{m}^{3} \mathrm{ha}^{-1}$ ) in stands with different initial densities (trees ha ${ }^{-1}$ ) and thinning criteria: $\mathrm{KKC} 1$-thinning is done when the relative stand density reaches 0.95 and is then reduced to 0.7; KKC2 - thinning is done when the relative stand density reaches 0.95 and is then reduced to 0.45 ; KKC 3 -thinning is done when the relative stand density reaches 0.95 , and in the first commercial thinning it is reduced to 0.45 and in the second thinning to 0.7 .

\section{References}

1. Gregow, H.; Laaksonen, A.; Alper, M.E. Increasing large scale windstorm damage in Western, Central and Northern European forests, 1951-2010. Sci. Rep. 2017, 7, 46397. [CrossRef] [PubMed]

2. Hanewinkel, M.; Cullmann, D.A.; Schelhaas, M.; Nabuurs, G.; Zimmermann, N.E. Climate change may cause severe loss in the economic value of European forest land. Nat. Clim. Chang. 2012, 3, 203-207. [CrossRef]

3. Ministry of Agricuiture Republic of Latvia. Available online: https://www.zm.gov.lv/public/ck/files/skaitli\& fakti_EN_2017.pdf (accessed on 17 May 2020).

4. Nieuwenhuis, M.; Fitzpatrick, P.J. An assessment of stem breakage and the reduction in timber volume and value recovery resulting from a catastrophic storm: An irish case study. Forestry 2002, 75, 513-523. [CrossRef]

5. Dubrovskis, E.; Donis, J.; Racenis, E. Wind-induced stem breakage height effect on potentially recovered timber value: Case study of the Scots pine (Pinus sylvestris L.) in Latvia. For. Stud. 2018, 69, 24-32. [CrossRef]

6. Kärhä, K.; Anttonen, T.; Poikela, A.; Palander, T.; Laurén, A.; Peltola, H.; Nuutinen, Y. Evaluation of salvage logging productivity and costs in windthrown Norway spruce-dominated forests. Forests 2018, 9, 280. [CrossRef]

7. Schwarzbauer, P.; Rauch, P. Impact on industry and markets-Roundwood prices and procurement risks. In Living with the Storm Damage; Gardiner, E., Schuck, A., Schelhaas, M.-J., Orazio, C., Blennow, K., Nicoll, B., Eds.; European Forest Institute: Joensuu, Finland, 2013; pp. 64-70. 
8. Thürig, E.; Hagedorn, F.; Lindroth, A. Influence of storm damage on the forest carbon balance. In Living with the Storm Damage; Gardiner, E., Schuck, A., Schelhaas, M.-J., Orazio, C., Blennow, K., Nicoll, B., Eds.; European Forest Institute: Joensuu, Finland, 2013; pp. 47-55.

9. Thürig, E.; Palosuo, T.; Bucher, J.; Kaufmann, E. The impact of windthrow on carbon sequestration in Switzerland: A model-based assessment. For. Ecol. Manag. 2005, 210, 337-350. [CrossRef]

10. Thorn, S.; Bässler, C.; Svoboda, M.; Müller, J. Effects of natural disturbances and salvage logging on biodiversity-Lessons from the Bohemian Forest. For. Ecol. Manage. 2017, 388, 113-119. [CrossRef]

11. Blennow, K. Adaptation of forest management to climate change among private individual forest owners in Sweden. For. Policy Econ. 2012, 24, 41-47. [CrossRef]

12. Moench, M. Adapting to climate change and the risks associated with other natural hazards: Methods for moving from concepts to action. In Earthscan Reader in Adaptation to Climate Change; Schipper, E.L., Butron, I., Eds.; Eascan: London, UK, 2007; pp. 14-48.

13. Gardiner, B.A.; Welten, P. Mitigation of forest damage. In Living with the Storm Damage; Gardiner, E., Schuck, A., Schelhaas, M.-J., Orazio, C., Blennow, K., Nicoll, B., Eds.; European Forest Institute: Joensuu, Finland, 2013; pp. 79-87.

14. Hanewinkel, M.; Peyron, J.L. The economic impact of storms. In Living with Storm Damage to Forests: What Science Can Tell Us Joensuu; Gardiner, B., Schuck, A., Schelhaas, M.-J., Orazio, C., Blennow, K., Nicoll, B., Eds.; European Forest Institute: Joensuu, Finland, 2013; Volume 5, pp. 55-63.

15. Mason, B.; Valinger, E. Managing forests to reduce storm damage. In Living with the Storm Damage; Gardiner, E., Schuck, A., Schelhaas, M.-J., Orazio, C., Blennow, K., Nicoll, B., Eds.; European Forest Institute: Joensuu, Finland, 2013; pp. 87-97.

16. Wallstedt, A. Återväxtstöd efter stormen Gudrun. In Rapport 1 [Subsidies for Silviculture after the Storm Gudrun. Report 1]; Skogsstyrelsen: Jönköping, Sweden, 2013; p. 43.

17. Wallgren, M.; Bergström, R.; Bergqvist, G.; Olsson, M. Spatial distribution of browsing and tree damage by moose in young pine forests, with implications for the forest industry. For. Ecol. Manag. 2013, 305, 229-238. [CrossRef]

18. Schou, E.; Jellesmark Thorsen, B.; Bredahl Jacobsen, J. Regeneration decisions in forestry under climate change related uncertainties and risks: Effects of three different aspects of uncertainty. For. Policy Econ. 2015, 50, 11-19. [CrossRef]

19. Peltola, H.; Kellomäki, S.; Väisänen, H.; Ikonen, V.-P. A mechanistic model for assessing the risk of wind and snow damage to single trees and stands of Scots pine, Norway spruce, and birch. Can. J. For. Res. 1999, 29, 647-661. [CrossRef]

20. Peltola, H.; Kellomäki, S.; Hassinen, A.; Granander, M. Mechanical stability of Scots pine, Norway spruce and birch: An analysis of tree-pulling experiments in Finland. For. Ecol. Manag. 2000, 135, 143-153. [CrossRef]

21. Valinger, E.; Fridman, J. Factors affecting the probability of windthrow at stand level as a result of Gudrun winter storm in southern Sweden. For. Ecol. Manag. 2011, 262, 398-403. [CrossRef]

22. Donis, J.; Kitenberga, M.; Snepsts, G.; Dubrovskis, E.; Jansons, A. Factors affecting windstorm damage at the stand level in hemiboreal forests in Latvia: Case study of 2005 winter storm. Silva Fenn. 2018, 52, 1-8. [CrossRef]

23. Zubizarreta-Gerendiain, A.; Pellikka, P.; Garcia-Gonzalo, J.; Ikonen, V.P.; Peltola, H. Factors affecting wind and snow damage of individual trees in a small management unit in Finland: Assessment based on inventoried damage and mechanistic modelling. Silva Fenn. 2012, 46, 181-196. [CrossRef]

24. Albrecht, A.; Hanewinkel, M.; Bauhus, J.; Kohnle, U. How does silviculture affect storm damage in forests of south-western Germany? Results from empirical modeling based on long-term observations. Eur. J. For. Res. 2012, 131, 229-247. [CrossRef]

25. Zeng, H.; Peltola, H.; Talkkari, A.; Venäläinen, A.; Strandman, H.; Kellomäki, S.; Wang, K. Influence of clear-cutting on the risk of wind damage at forest edges. For. Ecol. Manag. 2004, 203, 77-88. [CrossRef]

26. Methodology of National Forest Inventory. Available online: http://www.silava.lv/userfiles/file/Nacionalais\% 20meza\%20monitorings/Me\%C5\%BEa\%20resursu\%20monitoringa\%20metodika\%2026_04_2013.pdf (accessed on 15 March 2020).

27. Gardiner, B.A.; Suárez, J.; Achim, A.; Hale, S.E.; Nicoll, B.C. ForestGALES A PC-Based Wind Risk Model User's Guide; Version 2.0; Forest Research: Roslin, UK, 2004. 
28. Gardiner, B.A.; Byrne, K.; Hale, S.E.; Kamimura, K.; Mitchell, S.J.; Peltola, H.; Ruel, J.C. A review of mechanistic modelling of wind damage risk to forests. Forestry 2008, 81, 447-463. [CrossRef]

29. Zeng, H.; Garcia-Gonzalo, J.; Peltola, H.; Kellomäki, S. The effects of forest structure on the risk of wind damage at a landscape level in a boreal forest ecosystem. Ann. For. Sci. 2009, 67, 111. [CrossRef]

30. Ahti, T.; Hämet-ahti, L.; Jalas, J. Vegetation zones and their sections in northwestern Europe. Ann. Bot. Fenn. 1968, 5, 169-211.

31. Donis, J.; Snepsts, G.; Zdors, L.; Zarins, J. Improvement of the Growth Models. 2018. Available online: http://www.silava.lv/userfiles/file/Projektu\%20parskati/2018_Donis_LVM.pdf (accessed on 15 March 2020).

32. Quine, C.P. Estimation of mean wind climate and probability of strong winds for wind risk assessment. Forestry 2000, 73, 247-258. [CrossRef]

33. Central Statistical Bureau of Latvia Forestry Report. 2018. Available online: https://www.csb.gov.lv/en/ statistics/statistics-by-theme/agriculture/forestry/tables/metadata-forestry. (accessed on 15 March 2020).

34. Ozolins, R. Forest stand assortment structure analysis using mathematical modelling. For. Stud. Uurim. 2002, $37,33-42$.

35. Klempered, W.D. Forest Resource Economics and Finance. McGraw-Hill Series in Forest Resources. U.S.A.; McGraw-Hill Inc.: New York, NY, USA, 1996.

36. Schindler, D.; Bauhus, J.; Mayer, H. Wind effects on trees. Eur. J. For. Res. 2012, 131, 159-163. [CrossRef]

37. Zeng, H.; Peltola, H.; Väisänen, H.; Kellomäki, S. The effects of fragmentation on the susceptibility of a boreal forest ecosystem to wind damage. For. Ecol. Manag. 2009, 257, 1165-1173. [CrossRef]

38. Gardiner, B.A.; Quine, C.P. The Mechanical Adaptation of Trees to Environmental Influences. Plant Biomech. 2000, 2, 1-13.

39. Gregow, H. Impacts of Strong Winds, Heavy Snow Loads and Soil Frost Conditions on the Risks to Forests in Northern Europe; Ilmatieteen laitos: Helsinki, Finland, 2013.

40. Katrevičs, J.; Džerina, B.; Neimane, U.; Desaine, I.; Bigača, Z.; Jansons, Ā. Production and profitability of low density Norway spruce (Picea abies (L.) Karst.) plantation at 50 years of age: Case study from eastern Latvia. Agron. Res. 2018, 16, 113-121.

41. Lībiete, Z.; Donis, J.; Jansons, J.; Zālītis, P. Growth potential of even-aged spruce forest. In Even-Aged Spruce Stands in Latvia; Jansons, J., Ed.; Daugavpils Universitātes akadēmiskais apgāds "Saule": Daugavpils, Latvija, 2014; pp. 11-55.

(C) 2020 by the authors. Licensee MDPI, Basel, Switzerland. This article is an open access article distributed under the terms and conditions of the Creative Commons Attribution (CC BY) license (http://creativecommons.org/licenses/by/4.0/). 